\title{
URBANISATION, ELITE ATTITUDES AND PHILANTHROPY: CARDIFF, 1850-1914*
}

How did philanthropy adjust to the transformation of society in the nineteenth century? What was its role in social relations and in relieving poverty? Recent writers studying these issues have suggested the need for detailed studies at local level, and in studying some English towns and cities in the earlier part of the nineteenth century they have come to varying conclusions. Roger Smith's study of Nottingham shows that philanthropy added insignificantly to the amount of relief available through the Poor Law. ${ }^{1}$ By contrast Peter Searby's study of Coventry shows that philanthropic funds were quite abundant and after some reforms in the 1830 's even applied to the relief of the poor! ${ }^{2}$ Professor McCord's articles on the North-East of England in the early nineteenth century seek to establish the more ambitious claim "that nineteenth-century philanthropy provided increasing resources and extended machinery with which to diminish the undesirable effects of that period's social problems". ${ }^{3}$

As yet, there has been no attempt to study philanthropic provision in a newly developing town without an industrial tradition in the late nineteenth century. Professor McCord recognises that charitable effort became less appropriate in the "much more complicated and sophisticated" society of the late nineteenth century, but he does not analyse the

* I would like to thank Martin Daunton, Jon Parry, Michael Simpson, Peter Stead, John Williams and the editors of this journal for their helpful comments on earlier drafts of this article, and Non Jenkins for her help in locating some uncatalogued material in the National Library of Wales. The staff of Cardiff Central Library have been helpful over many years.

1 R. Smith, "The Relief of Poverty outside the Poor Law, 1800-1850: A Study of Nottingham", in: Midland History, II (1974).

2 P. Searby, "The Relief of the Poor in Coventry, 1830-1863", in: Historical Journal, XX (1977).

${ }^{3}$ N. McCord, "Aspects of the Relief of Poverty in Early 19th-Century Britain", in: The Long Debate on Poverty (London, 1972); id., "The Poor Law and Philanthropy", in: The New Poor Law in the Nineteenth Century, ed. by D. Fraser (London, 1976), quotation from p. 110. 
reasons for this development. Generally he is reticent about the social determinations of philanthropy, believing with the philanthropists themselves that the existence of charities testified "to the presence of strong inclinations towards co-operation and sympathy between different elements in society". 4 The key to the problem, in his view, is the growth of humanitarian sentiment. Vital questions about the nature of historical change are begged, and it is the intention of this article to discuss some of these issues in the context of evidence from nineteenth-century Cardiff.

Certainly philanthropic resources increased in the nineteenth century, but did they do so in pace with the needs of the poor and the growing wealth of the middle classes? What induced the middle classes to give their money to charities? Humanitarianism is too timeless an answer to this problem, and we need to ask what constraints operated on a middle-class humanitarian in the nineteenth century, recognising as Schumpeter did that relief "had to fit in with the given political pattern and with the given social system". ${ }^{5}$ Christian humanitarianism could have followed the precepts of the New Testament literally and given everything to the poor; few, if any, of the charitable did this. Instead, a form of humanitarianism compatible with a highly unequal society was found. How did the way in which philanthropists and the middle classes perceived urban society affect the way they responded to philanthropic appeals? These questions will recur in the following discussion, but first it is necessary to examine some of the peculiarities of Cardiff's nineteenth-century development, in the context of the general difficulties which urban growth presented in the nineteenth century.

Mid-nineteenth-century Cardiff was particularly ill-adapted to provide philanthropic relief for the poor. Its history had been undistinguished and the 1801 census revealed a population of 1,871 persons. It was little more than a village which by an accident of history had the dignity of a municipal corporation added to it. In the first fifty years of the nineteenth century its population multiplied ten times to reach a still modest 18,351 in 1851. This growth was the result of the opening of the Glamorganshire Canal in 1794, and of the dock and railway development of 1839-41. These transport changes made Cardiff the chief outlet for the mushrooming iron

4 Id., "The Poor Law and Philanthropy", pp. 95, 109.

5 J. A. Schumpeter, History of Economic Analysis (New York, 1954), p. 147, cited in G. V. Rimlinger, "Welfare Policy and Economic Development: A Comparative Historical Perspective", in: Journal of Economic History, XXVI (1966), p. 559. 
town of Merthyr Tydfil in the interior. Such a background did not provide it with a vast range of endowed charities, as was the case in London or York. When the Brougham Commissioners visited it in the 1830's, they found few charities to report on and a picture of maladministration in those which did exist. There were nine charities. Two were educational and of these one had lapsed, the other had lapsed for a period between 1792 and 1816. Five provided doles for the poor, but only two of these operated as intended, the others having lapsed or (in one case) being applied to the poor rates. An almshouse once in existence had also lapsed. The wealth of the past, then, had not equipped a town which was now rapidly growing for its needs. This was often the case in rapidly developing areas; the legacy of previous philanthropy did not coincide with the growth of the present. Liverpool also lacked any vast bounty of endowed wealth, while towns of slower development like London, York and Bristol were relatively well endowed with funds. ${ }^{6}$

Nor was mid-nineteenth-century Cardiff well provided with voluntary organisations with charitable aims. The social structure did not allow this. The central political and economic fact was the unusual domination exercised by the estate of the Marquess of Bute, which owned much of the local land and had for a long period controlled the political life of the borough. Its domination was buttressed by philanthropy and the second Marquess (1793-1848) was well remembered in Cardiff for his benevolence. It has been estimated that between 1827 and 1848 he paid between $£ 20,000$ and $£ 25,000$ to charities in Glamorgan, and in hard times he distributed coal and blankets to the poor of the borough. There was no established wealth in the town which could in any way rival that of the Bute Estate, and this severely limited the amount of charity which could be provided. Some of the wealth of the town had gone into the foundation of the Glamorgan and Monmouthshire Infirmary in the 1830's; but this was a venture which drew on a wider geographical base, as the name of the institution indicated. There were other, small-scale, less well supported institutions - a Benevolent Loan Association, a Sympathetic Society, a Visiting Society and a Merchant Seamen's Hospital Fund, for instance. In addition there was irregular personal aid given to the poor - impossible to

6 W. Rees, Cardiff: A History of the City, 2nd ed. (Cardiff, 1969), p. 297; H. Carter, "Phases of Town Growth in Wales", in: The Study of Urban History, ed. by H. J. Dyos (London, 1968); Report on Endowed Charities, County Borough of Cardiff [Parliamentary Papers, 1897, LXVII] (this reprints the 1837 report); D. Owen, English Philanthropy 1660-1960 (London, 1965), pp. 276, 444, 447-49; M. Simey, Charitable Effort in Liverpool in the Nineteenth Century (Liverpool, 195I); H. E. Meller, Leisure and the Changing City, 1870-1914 (London, 1976), ch. 2. Despite its slow growth Bristol had severe public-health problems. 
quantify, but it was a standby of newspaper obiturists that the departed had been good to the poor - and there was a growing philanthropic provision for education. A Church School was opened in 1815, with the Bute Estate closely involved, and provision by other religious bodies followed this. But philanthropic efforts could not keep pace with the vast growth of population; in 1852 there were places for half the children of the town, in 1871 for only one third. ${ }^{7}$ The smallness and small-scale fortunes of the local elite imposed severe limits on benevolence. This was in marked contrast with a town like Bristol, where vast eighteenth-century expansion had created a large and prosperous middle class and, because its nineteenth-century expansion was relatively slow, the community faced less intense social problems in the nineteenth century. In Cardiff, the shortfall of resources was immense, as immense as Bristol's relative abundance. This was not merely a local pattern produced by the peculiarities of development on either side of the Bristol Channel in the eighteenth and nineteenth centuries. It may have been especially marked there, but many centres of industrial growth, such as cotton towns or coal-mining areas found similar imbalances.

It must be emphasised that philanthropy has to be related to the local social structure and particular patterns of growth. It would be unwise to equate the social problems of the nineteenth century simply with urban growth or industrialisation. However, it must be recognised that philanthropy expanded against a background of social transformation. It faced the problem of hitting a moving target. Size did not automatically increase needs - much would depend on the basis of the local economy and the regularity of employment which was generated. London expanded at a rate less rapid than did many nineteenth-century towns, but the expansion of casual employment there made it a suitable case for charity. So while we cannot read off the extent of local needs simply from the rate of population growth, neither can we ignore this factor. Professor McCord concentrates upon the growth of philanthropic resources, and never confronts this vital issue. Need is not capable of simple definition, but to ignore the pressures generated by population explosion is to neglect the essential context. Many areas of rapid growth were remote from the middle class and benevolence; deprivation (as is now being recognised) has spatial

7 J. Davies, "Glamorgan and the Bute Estate" (unpublished Ph.D. thesis, University of Wales, 1969); N. Evans, "The First Charity in Wales': Cardiff Infirmary and South Wales Society, 1837-1914", in: Welsh History Review, IX (1978-79); Cardiff and Merthyr Guardian, 31 May and 10 July 1834; 3 January and 14 September 1835; 26 March 1836; 9 December 1837; Ch. Morgan, "Education in Cardiff", in: Cardiff: An Illustrated Handbook, ed. by J. Ballinger (Cardiff, 1896). 
aspects. ${ }^{8}$ The poor of Newcastle had access to the range of facilities which Professor McCord describes, but in the adjoining coalfield the provision was more limited. It has recently been demonstrated that in the Deerness Valley in County Durham the Pearse family exercised paternal control through the subsidising of chapels and housing, and providing coal in hard times. Yet it can be argued that this was not characteristic of the British coalfields, and that even in the Deerness Valley the philanthropy was not continuous. The rapidly growing South Wales coalfield has been described as a "neglected society", and here coal-owners rarely provided housing, unless it was unavoidable. ${ }^{9}$ Well-established cities with strong and wealthy elites were always more likely to be endowed with charitable resources than booming and expanding industrial areas.

The second half of the nineteenth century saw Cardiff transformed again. By 1911 its population had risen to 182,259 , a multiplication of ten times in the second half of the nineteenth century or of a hundred times in the period 1801-1911. The norm for a rapidly expanding town in the nineteenth century was an increase of about nine times. Cardiff's vast percentage increase in size was, of course, partly the product of the low base figure, but the low base meant that its philanthropic resources were extremely small and had to cope with vast problems. The growth of Cardiff in the late nineteenth century was the product of the development of the South Wales coal trade from the 1840's onwards. By the Edwardian period this had made Cardiff (in the words of the South Wales Daily News) "the coal Metropolis of the World". In the town itself traders, entrepreneurs in service industries and professional interests flourished, while around the expanding docks grew a class of merchants, shippers, brokers and coalowners. Most of the latter had their major assets tied up in the South Wales coalfield and were not major employers of labour in the town itself. Cardiff was the commercial and transport centre of the Eastern part of the coalfield. The elite could be persuaded to part with some of its money for philanthropic agencies in the town, but they were always somewhat distanced from it, in the town rather than of it. ${ }^{10}$ The way the elite viewed

8 This theme is prominent in much recent urban sociology. For a brief introduction see R. E. Pahl, Whose City?, 2nd ed. (Harmondsworth, 1975), ch. 8, esp. pp. 167-71.

9 R. Moore, Pitmen, Preachers and Politics (Cambridge, 1974), ch. 3; E. P. Thompson, "On History, Sociology and Historical Relevance", in: British Journal of Sociology, XXVII (1976), pp. 392-93; M. J. Daunton, "Miners' Houses: South Wales and the Great Northern Coalfield, 1880-1914", in: International Review of Social History, XXV (1980); J. Morris and L. J. Williams, The South Wales Coal Industry, 1841-75 (Cardiff, 1958), ch. IX and p. 209; L. J. Williams, "The Coalowners", in: A People and a Proletariat, ed. by D. Smith (London. 1980), pp. 106-10.

10 M. J. Daunton, Coal Metropolis: Cardiff 1870-1914 (Leicester. 1977), esp. chs 2, 3 and 4. 
Cardiff had important implications for the development of philanthropy after 1850. It is essential to leave the rather abstract grounds of the imbalance between resources and needs. Such an emphasis, while it is essential context, does not explain the way in which philanthropy developed. To argue that it did would be to assume, in a simplistic manner, that as needs emerged and were recognised they were fulfilled to the extent that resources permitted. This would be to ignore the influence which ideology and perceptions of urban society had on the middle class. For their contributions to philanthropy were deeply influenced by the way in which they saw the urban society which confronted them and by the benefits which they could possibly gain from philanthropy. "Need" was relative to the position of the observer. Humanitarianism had to square with the existing structure of society and the distribution of power.

Victorian philanthropy was a complex and varied phenomenon. Brian Harrison argues convincingly that a wide approach is desirable, and that this should include temperance, sabbatarianism, reform movements, pressure groups and church building, in addition to the relief and socialwork agencies which are more usually regarded as being within the purview of philanthropy. His definition "will include any organisation devoting money, time, thought or energy to relieving the miseries of the poor, the neglected or the oppressed". ${ }^{11}$ It is possible to extend the definition to even wider limits, as does Professor Robert Bremner, the historian of American philanthropy. "The aim of philanthropy in its broadest sense is the improvement in the quality of human life."12 Some philanthropic activities such as the foundation of universities or art galleries benefited the middle classes rather than the poor. The interest of the Cardiff poor in the University College or the Turner Gallery must have been minimal. ${ }^{13}$ For present purposes Dr Harrison's definition is the most serviceable; by including a wide range of activities it allows us to see philanthropy in its historical context and does not restrict the activity to material relief. Yet by restricting the subject to measures aimed at the poor it is more precise than Professor Bremner's conception, in which breadth threatens to become

11 B. Harrison, "Philanthropy and the Victorians", in: Victorian Studies, IX (1965-66), p. 351 .

12 R. Bremner, American Philanthropy (Chicago, 1960), p. 3.

13 Cardiff Times (hereafter CT), 30 June 1888, gives an account of the opening of Turner House. Ibid., 27 October 1883, deals with the opening of the University College of South Wales and Monmouthshire. 
nebulousness. It is vital that philanthropy is not passed through the filters of hindsight in order to view it as an ancestor of the Welfare State, but rather it must be viewed in its social context. This involves recognising that philanthropy involved the provision for the poor of what the philanthropist thought necessary and not simply the meeting of neutrally defined needs. Benevolence cannot be wrenched from its social and historical context. In Cardiff the giving of doles was not a central feature of the philanthropic scene, but because of the nature of its development other activities were more important. Dr Harrison's definition is wide enough to grasp the social reality of philanthropy and sets the subject firmly in the realm of class relations.

Out of the variety of nineteenth-century philanthropy there were numerous possible options for support and various ways of giving support. The kinds of institutions supported and the kind of support given varied between different sections of the elite and with age and sex. The range of provision which had developed by the early twentieth century is illustrated by the useful directory of charities produced by the Cardiff Charity Organisation Society in 1910. This listed 51 charities available to local inhabitants, but by eliminating those run by local authorities and some double counting of what were essentially different branches of the same organisations we are left with 44 bodies. There were obvious omissions the YMCA, the COS itself and the Cardiff and District Citizen's Union for instance find no place in its pages. If we add these three to appropriate categories (the COS, to its horror, as a dole-giving society!) the following table emerges:

Type of charity

Number

Medical (including aid to deaf and dumb, blind and crippled)

Convalescent homes

Animals

Aged and/or children

Prostitution and/or crime 8

Young men and women 4

Sailors (not including missions to seamen, Seamen's Hospital classed as Medical)

Doles and lodging

Differing definitions of charity, of course, limit the effectiveness of such counting - religious missions, schools and many other institutions are 
excluded - , but this does give some indication of the concern of charities by the late nineteenth century. If we add the medical charities to the convalescent homes, they are easily preponderant in number, but, more importantly, they represented the largest investment of capital, in building and in working expenses. The convalescent homes, it should be noted, were outside the town and drew on its financial support to an unknown degree. The most important feature of the charities offering doles was that they were generally closely associated with religious denominations or ethnic groups and had a limited clientele. Prostitution and crime was the other large group and this too represented some investment in bricks and mortar, though it should be added that such organisations were unstable. Several institutions known to have existed earlier had disappeared.

The institutions which existed in the early twentieth century can be classified into three major groups based upon the chronological period and the sections and ideologies within the elite which had produced them. Firstly, there were those charities based upon an Evangelical concern for crime and vice, which had emerged as the dominant response to a pervasive social crisis in the mid-Victorian era; many of these survived in a changed form and in the different context of the early twentieth century. They drew especially on the older elite of the town and on a particularly Christian response to urban problems. Secondly, there were the medical charities, hospitals especially, which produced imposing edifices and reflected on the status of the town in general. They gained a larger measure of their support from the dock interests, which could write the appropriate cheques and bask in the reflected glory, but contribute little else to their development. Lastly, there were the small-scale personal-service charities, which emerged around the turn of the century, based upon the aspirations and outlook of the professional groups - the Charity Organisation Society and the university settlement in particular.

The types of philanthropy, then, changed with the passing of time and varied in the type of support they could draw upon. The kind of philanthropic gift also varied, and with it varied the involvement of the different sections of the middle class. Many charitable societies gave personal service in addition to cash. Those established in the 1860 's did so especially - tract societies, visiting societies, Magdalen societies, seamen's missions all provided many opportunities for this. Some of the larger city-wide institutions did so too - the Infirmary, for instance, had a Lady Visitors' Committee. Often an intermediary was put between the donor and the recipient. The Town Mission used paid missionaries, homes for the reformation of prostitutes used paid help as well as voluntary work. The religious-based and highly localised charities of the early part of the period 
under discussion were more likely to use methods of direct contact, though this was not always the case. Women and young men had a vital role in such voluntary work. Charity began close enough to home for it to be seen as an extension of the domestic concerns of women - so they could distribute alms, run soup kitchens and visit the wards of hospitals. Young men could indulge in morally more risky ventures like distributing tracts to seamen or evangelising and preaching temperance under the auspices of the YMCA. Mature men signed the cheques and sat on committees. There was, then, a division of labour in philanthropic activities along age and sex lines.

\section{III}

Having outlined the general framework into which philanthropy had to fit and considered its nature as an activity, it is possible to examine the three broad groups of philanthropic agencies, which have already been outlined, as they developed in the course of the late nineteenth century. After the mid nineteenth century the scale and pace of philanthropic effort in Cardiff increased greatly. The reasons for this are not hard to find; they emerged out of the fears engendered by Cardiff's rapid development, and the poverty, crime, prostitution and drinking associated with it, combined with the impact of an Evangelical sense of responsibility for these ills on the part of some of the middle classes. The sense of crisis was compounded of the local situation and a more generalised sense of social dissolution. These fears were a local version or a manifestation of the "Condition of England" question. While this was debated in Britain generally largely in terms of the situation in the Northern textile towns, it could take a different form at the local level. In general terms the emphasis was on the novel problems of an industrial society, and especially its towns and industrial proletariat. Cardiff grew without any great industrial base and the manifestations of the crisis were different. Sailors, not millhands, were at its centre and the preponderant fear was of moral contamination. The focus of attention was Butetown - built as an area of merchants' houses, but rapidly overtaken by the sailor town and its attendant "immoral" leisure. Cardiff's peculiar development gave the crisis an edge, a correspondent to the Cardiff Times in 1861 saw the problem in this way:

Cardiff like many other towns of rapid development and increasing population has of late years outgrown its strength. Its commercial rise and progress may be compared to a promising youth who has been rendered weak in consequence of springing upwards too quickly. It is too tall for its age and consequently moves along with an uncertain and tottering gait. It trembles in the knee joints, often making one apprehensive that it will have 
a dreadful fall unless tenderly nurtured. It requires strengthening medicine and the best of medical treatment. ${ }^{14}$

The medicine suggested by this correspondent was a reduction of public expenditure and the cessation of a number of brothel prosecutions which were proceeding at that time. For other people and particularly for those of an Evangelical persuasion it was the brothels, the crime and the drink which caused the problems and public expenditure was perfectly justified if it could "civilise" the inhabitants of Cardiff. The Rev. and Mrs Nathaniel Thomas moved from Carmarthen to Cardiff in January 1856; Mrs Thomas's biographer gives a vivid sense of what the experience meant to her.

Cardiff being a large seaport town where men of all types and nationalities reside for the brief period intervening between one voyage and another, is sadly marred by the fearful plague-spot which generally disfigures such towns. Intemperance and debauchery emerging from their dens stride along the streets unmasked in broad daylight and wear no blush. [This] presented a shocking sight to our keen-sighted, pure-minded and sympathetic friend [and] at first filled her heart with horror, even dismay; but soon filled her with zeal for God's glory and the salvation of men and women. ${ }^{15}$

The salvation of men and women became the theme of philanthropic work in this period for those with an Evangelical zeal. George Smart, in addressing the annual soiree of the YMCA expressed the sense of personal responsibility for social problems.

Of an evening the state of Bute Street and Bute Road is a disgrace to everybody - a mile long - a mile of temptations (hear, hear). I of ten think some withering questions will be asked of us at the judgement day about that street. "Did you know its state - did you do anything to alter it?" [. . . ] those competent to judge say they know [...] no town of its size so bad as Cardiff. Then let us put our shoulder to the wheel and remove this blot from our otherwise promising town (hear, hear). ${ }^{16}$

Putting the shoulder to the wheel meant a number of different approaches to the various aspects of the blot. A number of these emerged in the 1850's and 1860's hoping to moralise the poor and to create a Christian City - indeed in the aftermath of the 1859 religious revival there were prayers for the conversion of the world. An assault began and continued on a relatively smaller scale throughout the period under review. In the process much of the initial élan was lost; the problems were immense,

${ }^{14}$ CT, 1 March 1861.

${ }^{15}$ D. Davies, Christ Magnified. The Life of Mrs. N. Thomas of Cardiff (London, n.d. [c. 1884]), pp. 24-25.

${ }^{16}$ CT, 22 October 1859. 
the solutions often unrealistic, and in the end the religious had to consolidate what they held rather than hoping to moralise the whole world or the whole town. For purposes of analysis, it is possible to divide the approaches used into a number of groups, though they ran concurrently and were all attempts to cope with the social problems which were seen as arising from the existence of a large "floating population" and the threat which this seemed to offer to the morals of the town. Repression, conversion and the provision of alternative facilities were applied in differing proportions to the various groups in the population.

1. There were attempts to provide alternative facilities and religious instruction for sailors.

2. Prostitutes were harried by the law and offered facilities for their reception into "respectable" society.

3. Alternative facilities were provided for young men seen to be in danger from corruption from Bute Street's attractions, and more generally there were attempts to provide respectable entertainment.

4. There were attempts to take religion and thrift into areas of poverty, to impose a discipline on the poor.

The institutions provided for these purposes were many, usually smallscale, often short-lived, and they have left few records of their work. A brief outline of their efforts can be provided.

Sailors were perceived as the centre of the problem, and the town's obvious economic dependence upon them led to a variety of means being tried to improve their lot. Seamen were seen as enduring a very hard life and having their privations added to by the unscrupulous on shore thieves, prostitutes and crimps, and various combinations thereof. But sailors were also portrayed as simple, gullible, easily led, and therefore in need of special protection. ${ }^{17}$ Though there had been sporadic attempts to provide for seamen before this, the efforts picked up in the 1850's and 1860's. This coincided with the great problems which the sailor town posed for the middle class. Crimping - the inducement of sailors to desert their ships when they entered port - was rife in this period and a part of the pervasive sense of crisis until it was resolved by fairly drastic "police" action by the Board of Trade in the 1870's. ${ }^{18}$ Philanthropy, then, was an aspect of a wider concern for the problems of "sailor town". The Bristol Channel Mission for Seamen was established in the early 1850's and used a yacht to take its chaplain to visit ships at anchor in Kingroad and Penarth roadstead, port congestion being turned to religious advantage. About the

${ }_{17}$ CT, 4 March 1864; 7 March 1874; Cardiff Sailors' Rest, Annual Report, 1912, p. 8.

18 M. J. Daunton, “'Jack Ashore': Seamen in Cardiff Before 1914”, in: Welsh History Review, IX. 
same time the Bute Estate recognised the needs of seamen, and appointed a chaplain and in later years a "floating church" and a shore church for seamen. In 1855, Sophia, Dowager Marchioness of Bute, caused a Sailors' Home to be opened at the docks in an attempt to provide some security on shore for sailors. It aimed at becoming self-sufficient, but despite relatively high boarding charges it needed philanthropic support, which increasingly came from a wider section of the elite. ${ }^{19}$

The early efforts to aid sailors were largely the work of the Bute Estate and of a cross-channel establishment. In the 1860's and after, the local elite became more closely involved. In 1866 a hospital ship was provided, supported by a voluntary levy on shipping; in 1903 this was turned into a permanent shore-based hospital. Further seamen's homes followed. The Sailor's Rest developed out of attempts to provide for coloured seamen in the 1880's. Rapidly it outgrew its facilities and it became increasingly dependent on the support of John Cory, Cardiff's "Prince of Philanthropists". Sectarian religious clashes within this institution led to the emergence of another Rest in 1910. Such institutions provided scope for aid by voluntary workers and aimed at providing counter-attractions from drink, dancing and prostitution. They were limited in scale and could never match the prodigious growth of the town. ${ }^{20}$

Prostitution was seen as needing similar but sterner measures. In the 1860 's the press was obsessed with crime and prostitution.

THE MORAL CONDITION OF CARDIFF. There are known to the police 20 returned convicts; 63 male and 66 female convicted thieves; 120 brothels and 420 prostitutes!

Repression and redemption went hand in hand. Former Chartist John Willett took advantage of the law which gave reward to any householder who would swear before a magistrate that a house was being used as a brothel. He became the paid secretary of a committee established in the autumn of 1859 to combat the "social evil". The rewards obtained from the borough financed this and a home for "penitents" which was provided. Ratepayers protested at the cost and the whole episode won a brief notoriety. There was already in existence a rather inconspicuous Cardiff Female Refuge Society, established in 1850, which had done some smallscale work amongst prostitutes. In 1860 a County Association for Providing

19 Cardiff and Merthyr Guardian, 27 January 1838; CT, 30 January 1863; 13 March 1864; 13 March 1869; Cardiff Tide Tables and Almanack, 1891, p. 112; 1906, p. 77.

${ }^{20}$ CT, 7 March 1874; 11 October 1902; 29 January 1910; Western Mail, 28 January 1910; Royal Hamadryad Seamen's Hospital, Annual Reports, 1872 and 1914; Cardiff Sailors' Rest, Annual Reports, 1910-14, and letter of explanation bound with these in the Cardiff Public Library. 
a Penitentiary for Fallen Women was established and located just outside the borough, in Llandaff. (Cardiff and Llandaff at that time accounted for about half of the indictable crimes in Glamorgan.) This body was prominently supported by the Church of England, notably by Alfred Ollivant, the Evangelistic and reforming Bishop of Llandaff. It continued to operate on a small scale until it moved to Penarth in the 1880 's, where it continued to exercise these functions, later adding the training of deaconesses to its roles. ${ }^{21} \mathrm{~A}$ number of other such homes can be traced, all small-scale and apparently short-lived: a Female Servants' Home in 1859, the Ladies Association for the Care of Friendless Girls and a home in Frederick Street. The YMCA and the YWCA contributed to this movement too. All these efforts were aimed either directly at reforming prostitutes or at rescuing girls seen to be in danger. The best course seemed to be conversion to domestic service, which could combine philanthropy with self-interest. Often there seemed to be something of a symbiotic relationship between the two trades, out-of-work or seduced domestics turning to prostitution as one of the few available alternatives and one which might seem to offer rather easier money and more freedom, in the short term, at least. Other refuges were established later by the Salvation Army in the late 1880's and by the Forward Movement in 1905. The Bute Estate financed the Convenant of the Good Shepherd, another refuge, from 1883 onwards. ${ }^{22}$

Repression of prostitution continued to be a concern too. The Cardiff Borough Act of 1862 contained clauses for dealing with prostitution, which were said to have driven some of the prostitutes outside the borough to ply their trade, in the then unincorporated suburbs of Roath and Canton. In the 1860's and 1870's there were discussions of the desirability of petitioning to have the Contagious Diseases Act extended to Cardiff. Prostitution dropped from prominence in the 1880's to re-emerge in the Edwardian period; a Vigilance Society, the Cardiff and District Citizens Union (es-

21 CT, 15 January, 15 February, 1, 8, 15 and 22 March, 9 July and 27 December 1861; 13 March 1863; 5 October 1866; 1st Report of the Cardiff Associate Institute for Improving and Enforcing the Laws for the Protection of Women (Cardiff, 1860); Cardiff Tide Tables and Almanack, 1882, pp. 76-78; 1883, p. 91; 1895, p. 128; 1896, p. 128; House of Mercy for South Wales and Monmouthshire, Annual Reports, 1863, 1865-66, 1868, 1870-72, 1875-77, 1880 and 1890; Llandaff Diocesan Magazine, June 1903.

${ }^{22} \mathrm{CT}, 1$ and 22 October 1859; 23 April 1870; Ladies Association for the Care of Friendless Girls (Cardiff, 1883); South Wales Daily News (hereafter SWDN), 8 December 1893; Cardiff and District Ladies Association for the Care of Friendless Girls, 24th Annual Report, 1906; Cardiff Tide Tables and Almanack, 1883, p. 90; 1884, p. 92; Western Mail, 20 April 1891; CT, 4 May 1908; Forward Movement, Women's Branch, Annual Reports of the Social Wing, 1904-05, 1905-06, 1909-10 and 1910-11. 
tablished 1908) and other organisations pressed for stricter enforcement of the law and more active police intervention. ${ }^{23}$

Parallel with this repression and rehabilitation there were attempts to provide alternative sources of entertainment and recreation in the hope that these would civilise and isolate the population from "contamination". Respectable young men were a particular concern and in November 1853 they were provided with the Cardiff YMCA, which aimed at "mental and spiritual improvement", but quickly these aims came into conflict with each other and it was dissolved in 1863. There had been persistent difficulties over how religious the institution was to be, and when the Cardiff Free Library was established, it provided competition (and without the substantial membership fee of the YMCA) in the mental aspect of the Association's work. It was reconstituted in 1879 without religious tests, with a greater emphasis on social activities and sport, and a much lower membership fee. In this form it prospered, acquired new premises and with the substantial aid of John Cory it acquired branches in various parts of Cardiff in the Edwardian period. ${ }^{24}$

Recreational facilities of a moral nature were a theme of the 1850's in Cardiff and not just confined to the activities of the YMCA for young men. Uplifting and educational penny readings became a veritable craze in the decade providing cheap and "uncontaminated" pleasure. Chapels ran mutual-improvement classes. Missions provided tea and magic-lantern shows. There were attempts to run a temperance music hall, and some preachers adopted a dramatic style in an attempt to turn religion into a form of entertainment. Sailors' Homes provided many of these facilities for seamen. In the 1880's temperance advocates began to provide coffee taverns as an alternative to the pub. The public library, run initially as a voluntary body before the 1855 Libraries Act was adopted, was meant to offer alternatives. Much of this was short-lived, ineffective and overwhelmed by secular or "immoral" leisure. ${ }^{25}$

23 CT, 8 January 1862; 5 October 1866; 20 April and 21 September 1867; Cardiff Medical Society, Minutes, 9 March 1876; M. J. Daunton, "Aspects of the Social and Economic Structure of Cardiff, 1870-1914" (unpublished Ph.D. thesis, University of Kent, 1974), pp. 491-94; Cardiff Tide Tables and Almanack, 1894, p. 130; Cardiff and District Citizen's Union, Annual Reports, 1909-10 and 1918-19. For the later role of the Citizen's Union, see N. Evans, "The South Wales Race Riots of 1919", in: Llafur, III (1980-83), pp. 9-10.

${ }_{24}$ CT, 15 March 1861; 7 November 1862; 16 January and 19 December 1863; 22 January, 12 February and 23 April 1870; 12 May 1883; Cardiff Tide Tables and Almanack, 1892, pp. 115-16; Cardiff YMCA, Annual Reports, 1857, 1894-96; id., Fourth Anniversary of Lads' Union (Cardiff, 1904); CT, 11 April 1908; 10 July 1909.

${ }_{25}$ CT, 15 October $1858 ; 8$ January, 12 February and 15 October $1859 ; 30$ January 1860 ; 12 May 1865; 12 October 1883; S. W. Allen, Reminiscences (Cardiff, 1918), pp. 57, 68-71. 
Finally there were attempts throughout this period to spread religious agencies amongst the working class. There were two aspects of this, firstly voluntary bodies founded explicitly for this purpose and secondly the extension activities of existing bodies. One attempt to reach non-attenders was the Town Mission established sometime before 1859. It was non-sectarian and based on a belief that a non-denominational approach would enable it to reach non-attenders. It sent missionaries visiting door-to-door, who urged attendance and promoted other activities: penny banks, the taking of temperance pledges, mothers' meetings, a Band of Hope and the rescue of fallen women. Occasionally material aid was given too. Tract Societies showed a similar concern to involve the "unconscious secularists" in religion. Sunday Schools were another method of converting the whole town - or at least of inducing more of the up and coming generation to come within the pale of the churches. In 1859 a lay committee conducted a canvass of the whole town of Cardiff in an attempt to open new schools, provide links between the existing ones and to "encourage each other in the religious instruction of the ignorant". One hundred and twenty-five people each canvassed between 65 and 100 houses in an attempt to encourage parents to send their children to any Sunday School, there being no particular denominational bias in this activity. The organisers saw it as having some success amongst the Welsh, English and Irish in descending order of effectiveness. Twenty-five years later a Cardiff minister thought Sunday Schools often lost their children to a secular society at adulthood, but that taking an interest in other people's children was a vital bond and tended to blur class differences. Whatever Sunday Schools lost in terms of religious observance they made up for in terms of social control. ${ }^{26}$

Churches made significant efforts to extend religious agency in the town with chapel and mission building, and attempts to provide extra clergy. Such activity went beyond the ordinary concerns of churches and should be seen as an attempt to provide a service for the poor, and hence as an aspect of philanthropy. Initially, at least, this had some impact. The census returns of 1871 and 1881 showed a favourable shift in the ratio of clergy to total population, though by 1911 this had fallen back and was by then below the figure for 1851 . In 1851 Cardiff provided seating for $45 \%$ of its population, and in 1882 an estimate of provision again put the figure at $45 \%$ and attendance at about $30 \%$. In the growing suburb of Roath these

26 Cardiff Town Mission, Annual Reports, 1878-79, 1889 and 1898; CT, 8 January 1859; 4 February 1860; 14 February 1862; 6 March 1863; 6 April 1867; 15 April 1871; Christian Endeavour and its Results: A Short Narrative of the Cardiff Sunday School Canvass Movement (Cardiff, n.d.); C. J. Thompson, The Defects of Sunday Schools and How to Remedy Them (Cardiff, 1889), p. 5. 
figures were $20 \%$ and $15 \%$, respectively. In this context the missionary work of the Bible Christians in Roath enjoyed some limited success, but with a chapel holding 600 there were only 300 attenders on Sunday evening and 300 scholars in 1881 . Other churches provided missions or founded causes in developing areas of the town. Bethany Baptist Church was famous for its policy of extension and known as "the mother of churches". The Rev. A. Tilly left this prosperous cause (apparently with no prior doctrinal rift) to establish a new one at Tredegarville in Roath. Immense amounts of money were spent on church building and some of it was used for missions in poorer areas. Increasingly show business entered too, in the form of huge stage-managed revivals: Sankey and Moody came in 1882, Torrey and Alexander in 1904, and Alexander and Chapman in 1910. But revivals did not succeed in making masses of new converts and were attended by doubts about their efficacy. ${ }^{27}$ It was observed in the 1860's that revivals needed following up and constant effort if they were to produce any lasting effects; by the Edwardian period it was being openly doubted whether they reached many people who were not already members of churches and chapels. Instead of converting the world they were consolidating and reviving the morale of an increasingly beleaguered Christian community. They were part of a distinct religious subculture, increasingly isolated from the secular world, which Dr Kent finds to be one of the key features of the cultural landscape of the late-Victorian city. ${ }^{28}$ As in other fields the high spirits and optimism at the possibilities of moralising the poor in particular and the city in general had become deflated by secularism and the dispiritingly poor results gained from much of this effort. The poor and many of the wealthy were resistant, and increasingly resistant, to the appeals of the moralising gospel of the 1850 's and 1860 's.

IV

In order to understand the factors which influenced the success and failure of this group of voluntary efforts (and as context for the subsequent examination of the other kinds of charities) it is necessary to analyse

27 Home Office Papers 129/581, Religious Census, Public Record Office, London; The Religious Census of 1851: A Calendar of the Returns Relating to Wales, ed. by I. G. Jones and D. Williams (Cardiff, 1976), I, pp. 137-45; Census of England and Wales, 1851-1911; W. F. James, Seven Years' Pioneer Mission Work in Cardiff, 2nd ed. (London, 1882), p. 8; CT, 10 February and 12 May 1865; 8 September 1882; 20 August and 1 October 1904; Christian Herald, April 1910, Supplement: Spread the Fire Souvenir.

28 CT, 27 March 1863; 1 October 1904; J. Kent, "The Role of Religion in the Cultural Structure of the Late Victorian City", in: Transactions of the Royal Historical Society, Fifth Series, XXIII (1973). 
the motivations which underlay philanthropy. The best evidence for this comes from the appeals used by philanthropists to win support and their various public pronouncements. Gareth Stedman Jones isolates three basic features of gift relationships, which are confirmed by the evidence of philanthropic utterances and acts in late-nineteenth-century Cardiff. The gift (he argues) aids the personal salvation of the giver by providing a sacrifice in atonement for excessive wealth. Secondly, it assures the givers of their status and prestige. Furthermore, it implies an obligation on the part of the recipient; it is a form of social control. ${ }^{29}$ The first of these points, atonement for excessive wealth, was well put by the Rev. Joseph Waite.

It is sad, for instance, when in the midst of the comfort, the plenty, the joy of our home life, to be reminded that there is a world of suffering and distress, whose cry of agony is ever sounding at our doors; but we must listen to that cry and must sacrifice something in order to respond to it, if we would not fall into the condemnation of those who basely turn to a selfish use the gifts of God's providence. ${ }^{30}$

Atonement could have a more secular aspect, as the Rev. Vincent Saulez revealed in asking for donations for a soup kitchen: "in the hope that it may incite others to help those from whom their wealth is gained, for poor would be the rich without the poor". Father Gastaldi was explicit about the fact that gifts were a step on the road to salvation: "I acknowledge the receipt of $£ 5$ from Mr. George Watson; for which charity I offer him my sincere thanks, and I pray Almighty God to reward him with his blessing." 31 In this case the donor received a religious blessing and some publicity in the press, which leads us to the second of Stedman Jones's points, the assurance of status.

Charitable gifts were well publicised in the nineteenth century. Annual reports printed lists of donors, newspapers reported donations to funds, and the laying of a foundation stone could be a public stage upon which to announce a large gift. It was clearly recognised that status was an important part in charitable appeals. "A Feature of the Report is the Classified List of Contributors, Patients and Cost", proclaimed the cover of the annual report of Cardiff Infirmary in 1911. The Llandaff School for the Deaf and Dumb ended an appeal with the words: "A List of Subscribers and Donations will be printed and circulated at the close of this appeal." The Bible Christian Mission sent out its appeals signed by prominent Christians, bearing the legend: "We cordially approve of the enterprise, and heartily commend it to the support of the Christian public." This was sent

${ }^{29}$ G. Stedman Jones, Outcast London (London, 1971), pp. 251-52.

${ }^{30}$ J. Waite, Three Sermons (Cardiff, 1865), p. 19.

${ }^{31}$ CT, 18 January $1861 ; 26$ January 1867. 
to the most likely subscribers first and thence progressively to the least likely, the latter being encouraged to subscribe by the length of the list in front of them. Competition and example were a large part of the raising of funds. The Cardiff Times announced: "CARDIFF FREE LIBRARY. The Trustees of the Marquess of Bute have presented this institution with a donation of five pounds. We shall be glad to make many such announcements." Or again, "The Charities of Cardiff are under everlasting obligation to Mr. Lewis Williams, who always turns up with his 5 guineas and sets the ball rolling." Frequently contributions were promised if a specified number of others gave a similar amount. In 1858 Canon Williams gave 1 guinea to the YMCA library on condition that twenty other gentlemen did the same. John Cory tried to harry others into sharing his concern for Cardiff Infirmary in the Edwardian period, in a similar way. Status was a potent weapon for enlarging the number of benevolent and one which could endure even if the Christian reasons for benevolence were on the wane. $^{32}$

Christians often claimed to offer social control too, occasionally in a spectacular form. At the time of the Paris Commune Colonel Stuart anticipated Halévy in arguing in favour of town missions.

The sad events which had taken place on the Continent of Europe had only strengthened his convictions and the opinions of Englishmen that the main foundation of the happiness and prosperity of the people must be based upon that attention to their moral culture and religious duties which it was the object of these Missions to awaken (hear, hear).

The dreary existence of the artisan made attendance at a place of worship a relief from the misery of life, and Alfred Thomas thought that

the discipline undergone, and the experience gained in the churches, not only made loyal subjects, but also the best citizens [and there were benefits conveyed to the community] by the lessons of morality taught and inculcated in our assemblages. ${ }^{33}$

The maintenance of obligation was a problem which any charity interposing a bureaucracy between donor and recipient faced, and the desire for control could conflict with the desire for status. Status demanded open-handedness and publicity, control required strict investigation and discrimination between cases. Achieving both was a difficult pose to

32 Cardiff Infirmary, Annual Report, 1911; Llandaff School for the Deaf and Dumb, Annual Report, 1874; James, Seven Years' Pioneer Mission Work, op. cit., pp. 42-43; CT, 30 October 1858; 28 March 1862; 3 April 1869; 24 January 1880; Cardiff Infirmary, Annual Reports, 1906-07.

${ }^{33}$ CT, 15 April $1871 ; 8$ September 1883. 
maintain and charities were rarely able to keep still enough to produce a clear image. The discipline could come through what was given. Philanthropic education, for instance, imposed its obligation in the classroom. The Cardiff Provident Dispensary gave a philanthropic supplement to self-help, charity was thus only received by those who were seen to be helping themselves. Cardiff Infirmary faced related problems which I have discussed elsewhere. Doles to the poor, however, seemed to be particularly prone to "abuse" (i.e. the transfer of a gift without the corresponding obligation being imparted). ${ }^{34}$

Religiously inspired philanthropists were a fairly small proportion of the middle class, and they faced problems of appealing to other sections of the class for their time and money. The appeal to status was probably the strongest weapon which they possessed, but it could be supplemented by the provision of entertainments in aid of philanthropy. It was another means of getting something back from the gift, and even if the Cardiff Times once complained at the lack of suitability of such a quid pro quo spirit in philanthropy, it was an expedient which charities increasingly used to raise funds. Brian Harrison has usefully reminded us that money intended for the poor percolated through many middle-class filters, though it ought to be added that the nature of nineteenth-century society made this a necessity as much as a waste. The inducements to give were weakening and philanthropists sought expedients to raise funds. The Infirmary held balls for this purpose. Concerts, soirees and lectures helped other institutions out of difficulties, Adelina Patti sang in aid of Cardiff Infirmary, one of the most inventive and successful institutions in this field. Its predecessor, the Dispensary, was the first organisation to hold a charity bazaar in the town (in 1828). In the 1870's and 1880's it raised funds through prize draws and by publishing a book entitled Ye Olde Englishe Fayre. In the quest for funds, bazaars and lectures overwhelmed the patience of the middle class; there could seem to be too many of them vying with each other. ${ }^{35}$

Charities had to exist in the world of middle-class attitudes and perceptions, and tailor their fund raising to these views. They were also deeply influenced by changes in the physical and social structure of the city. Mid-nineteenth-century benevolence was prodded by the perception of

34 Cardiff Provident Dispensary, Annual Reports, 1885-1914; Evans, “"The First Charity in Wales"', loc. cit., pp. 324-25; CT, 14 February 1880.

${ }^{35}$ CT, 11 January 1861; Harrison, "Philanthropy and the Victorians", loc. cit., p. 363; CT, 3 October 1859; 14 February 1862; 6 November 1869; 22 January 1870; 21 January and 1 April 1871; 24 January 1880; Cardiff Infirmary, Patti Charity Concert, $1905-$ Programme (Cardiff, 1905); Allen, Reminiscences, op. cit., pp. 153-54, 161-62; James, Seven Years' Pioneer Mission Work, p. 29: SWDN. 27 November 1893. 
urban crisis. A flood of charities issued from this, some of which survived until the end of the period under review; others did not. Few could expand at a pace which rivalled that of the town or its growing wealth. Paucity of evidence seems to forbid any quantification, but it is difficult to resist the impression that (to use Stephen Yeo's terms) charities occupied less of the organisational space in 1914 than they had in the 1860 's and 1870 's.${ }^{36}$ For the middle classes the needs which philanthropy had served earlier in the period were now either less pressing or being filled by different organisations. Part of the urge towards philanthropy had been the local fears for the development of the city, a feeling that rapid growth in a town so little prepared by its past for development would overwhelm the respectable, Bute Street would spill out into fashionable Crockherbton and Roath. The available solutions were largely voluntary activity, though pressure was exerted upon the Borough to police the vice districts more severely. The town was small, unhealthy and did not have a high degree of physical separation of classes - in a "walking city" this was not possible on any great scale, though of course some areas had a greater cachet than others. The crisis was partly the result of Butetown's transitional position between middle-class residential area and vice district. In the 1860's middle-class residents of the area complained to the magistrates about the sights that greeted their eyes. They succeeded in winning parts of the town and county elite into a crusade for moralisation. By the 1870's distinct signs of a "modern" urban structure with its starker physical separation of classes were becoming apparent, and in the 1890's it was necessary for a minister of religion to remind his congregation that the evils and blight of the docks area could spread outwards into the more fashionable parts of Cardiff. Such changes in the physical structure of the city made it increasingly difficult to mobilise reform crusades; those mustered in the late-Victorian and Edwardian periods relied more completely on Evangelicalism and less on a sense of urban crisis than those of the mid-Victorian period. By the late nineteenth century Evangelicalism too was less able to bear the weight. ${ }^{37}$ So, in general terms, it can be argued that the urgency of moralising the poor must have seemed greater in a more compact and unhealthy city than in a larger one with good drainage and a falling death rate.

36 S. Yeo, Religion and Voluntary Organisations in Crisis (London, 1976).

37 The term walking city is from S. B. Warner, Jr, Streetcar Suburbs (Cambridge, Mass., 1962). J. B. Hilling, "The Buildings of Cardiff", in: Glamorgan Historian, ed. by S. Williams (Cowbridge, 1969); C. R. Lewis, "A Stage in the Development of an Industrial Town: A Case Study of Cardiff, 1845-1875", in: Transactions of the Institute of British Geographers, New Series, IV (1979); CT, 30 August 1861; 22 September 1865; 9 December 1893. 
Middle-class fears about the social order are, of course, not a phenomenon confined to the middle of the nineteenth century, but they were less pervasive in the late nineteenth century. By then the sense of achievement in economic growth was less frequently assailed by doubts about moral health, and the viability of the whole enterprise. Hymns to the "Metropolis of Wales" had become more frequent than fears that Cardiff had an especially bad reputation for prostitution and crime. ${ }^{38}$ Where doubts remained there were now more institutions competing for space, more possible solutions. The police had been one possible solution in the 1860 's, and nonconformist attempts to control prostitution in the Edwardian period were increasingly in the form of pressure-group activity on public bodies. Political parties increasingly involved the working class in a subordinate role, and after the 1870 's the Board Schools provided a more potent instrument for moralising and disciplining the poor than the scattered and fragmented efforts of philanthropists could ever have done. The space was filled with leisure facilities which made it more difficult to attract the poor into "moralising" institutions. Religion had turned to innocent amusements in an attempt to enlarge its constituency in the 1860 's, but it could not compete with the increased commercial provision of leisure. Separate leisure facilities for the middle classes added to their cocoon of isolation - art societies, music societies, concerts and the theatre cut them off from both vulgar and commercial amusements. Moralising the poor might have been based initially upon an ideal of opening the windows of civilisation to all (as Meller argues), but increasingly the cultural aspects of this became the preserve of the affluent. ${ }^{39}$

In the course of the nineteenth century, religion and philanthropy became less important as agencies of social control. Religious institutions occupied less space by the late nineteenth century and increasingly the religious were forming themselves into a subculture in conflict with many of the emerging trends. This is not to argue that social control is either imposed or broken down, but to see it as a struggle which takes place in the realms of ideology and institutions. By the late nineteenth century there

38 For more detail on middle-class attitudes to Cardiff see N. Evans, "The Welsh Victorian City: The Middle Class, Civic and National Consciousness in Cardiff, 1850-1914", in: Welsh History Review, forthcoming.

39 Some of the arguments here owe much to Meller, Leisure and the Changing City, op. cit., and Yeo, Religion and Voluntary Organisations, op. cit., though, of course. I am responsible for my use of them; CT, 14 February, 8 May, 2 and 9 October 1880; 1 October 1885; and Allen, Reminiscences, passim, illustrate the growth of middle-class leisure facilities; Daunton, "Aspects", op. cit., p. 491. 
was a larger repertoire of such institutions, and religion and philanthropy occupied a relatively smaller place within it. ${ }^{40}$ In a sense this kind of philanthropy had been tried and seen to fail. When we recognise that it was all based upon an attempt to moralise, i.e. to impose values and attitudes arising from a different situation, this is hardly surprising. In the early, heady days of this movement there could be sweeping talk of converting the world or the town, but the rub came in the actual contact on the streets or in the Sailors' Rest. As one philanthropist recognised, "it is far easier to deal with men in masses or in generalisations than individually and alone." 41 For many, this kind of philanthropy was a constant fight against despair. The Town Mission controlled this by limiting the missionaries' visits to twenty minutes, and assessing its work in quantitative terms - the numbers visited became overarching. Reform societies maintained an air of boisterous enthusiasm for the prospects of their Magdalens, but despair could break through. A voluntary rescue worker with thirty years experience concluded that only a small proportion of girls who became prostitutes were "reclaimable" - "I have had enough of service", one told him. ${ }^{42}$ Small glimmers of hope were looked for to find a way through a despondency which threatened to be all-engulfing.

Those engaged in mission work, such as that of the Strangers' Rest, are sometimes tempted to think that because their efforts are not successful in bringing about a change in the life of those who come within their influence for a shorter or longer time, that therefore it is labour in vain.

During 1887, some incidents have come to our knowledge which have shown us definitely that God is able to carry on His work in men's souls by His own means, and that the "Word of God is not bound" either by time or place, or human instrumentality, that we want to tell our friends and helpers one or two of these stories. ${ }^{43}$

Obviously there was much morale in need of revival. The continuing vitality of philanthropy lay in other directions.

40 Here I am influenced by R. Johnson, "Educational Policy and Social Control in Early Victorian England", in: Past \& Present, No 49 (1970); J. R. Hay. "Employers' Attitudes to Social Policy and the Concept of 'Social Control', 1900-1920", in: The Origins of British Social Policy, ed. by P. Thane (London, 1978). G. Stedman Jones has modified his views on "social control", see "From Historical Sociology to Theoretical History", in: British Journal of Sociology, XXVIII; id., "Class Expression versus Social Control?", in: History Workshop, No 4 (1977).

41 Cardiff Strangers' Rest, Annual Report, 1887, p. 24.

42 SWDN, 5 December 1893.

43 Cardiff Strangers' Rest. Annual Report. 1887. p. 3. 
Many charities failed to expand rapidly in the course of the later nineteenth century. Some explanations for this in terms of the declining attractiveness of charities in general within the institutional structure of the late-nineteenth-century city have already been given. The characteristic institutions of the mid nineteenth century depended to a greater degree on localised and more personalised efforts. Different styles of philanthropy survived and expanded more easily in the late nineteenth century. They had a greater appeal to the large-scale capitalists of Cardiff, the dock and shipping interests, whose concern with the town was less direct and personalised than that of the older elite, which had launched the Evangelical institutions. But imposing edifices such as hospitals could be attractive to the dock interests: a hospital served a larger area than the town itself and was more congruent with the economic interests of this group than charities which were concerned to moralise the town itself. The large amounts of money needed for such ventures came more readily from the larger fortunes of the docks than from the tradesmen of the town. The dock interests were rather detached from the town, but paid their guineas out of a sense of duty, a due regard for their status and, perhaps more importantly, the status of the town. Money, it was said, was easier to raise than enthusiasm for charitable purposes. An intending philanthropist was advised to

do it on the grand scale and wait until you can. Cardiff is a town of big things. You will be taken at your own valuation and will probably find it easier to raise $£ 1000$ by a bold stroke, than $£ 100$ by timid touting. ${ }^{44}$

One minister of religion was so frustrated at his attempts at fund raising that on his departure from the city he launched a full-scale assault on the elite.

The wealthy merchants of the City reside outside its limits, and care little for the spiritual needs of their employees. With few exceptions, they do not interest themselves in anything which concerns the moral or intellectual well being of Cardiff. They not only decline to assist in the building of churches, but in the building and maintenance of the University College and the Infirmary as well. They have an unenviable reputation, and do not compare favourably with those who occupy similar positions in older

44 S. Hobson to Tom Jones and others, 25 February 1896. Thomas Jones Papers, Class X, Vol. 2, National Library of Wales, Aberystwyth. I am grateful to Baroness White of Rhymney and Mr Tristan Jones for permission to consult these papers. 
commercial towns, such as Bristol, Liverpool and Birmingham. They have no "pride of Citizenship". ${ }^{45}$

This swingeing attack hits a number of targets, but obscures some important points. It is true that the interests of the dock capitalists probably removed them from much concern for the small-scale, town-orientated charities which have been discussed, but as I have argued elsewhere they did respond to the needs of the Infirmary and made that the most successful charitable institution in the town (and probably in Wales) in the Edwardian period. Like the Seamen's Hospital it served a constituency which was much closer to the economic interests of the haute bourgeoisie, the proletariat of the town and its hinterland and the seamen, who were the lifeblood of an economy dependent upon the export of coal. There were special reasons for the failure to support the University. Education in Wales was particularly associated with nonconformity and the professional middle class; it was much influenced by Oxbridge values and concentrated on training teachers and preachers. Unlike the English civic universities the University of Wales' connections with industry and commerce were almost non-existent, so much so that the South Wales coal-owners financed an alternative technical institution, the Glamorgan School of Mines. Where no special circumstances like this intervened, the dock- and coal-owning classes were a source of finance, as they did in general share the enthusiasm for Cardiff"s emerging role as the "Metropolis of Wales". This promised to give them effective leadership of the whole of Wales, and the beautification of the city was a means of its achievement. They were less likely to be sympathetic to the kind of charity (church building, personal doles, etc.) which was close to the interests of the writer quoted above, and which depended upon a close interest in the town itself and its localities. ${ }^{46}$

An elite which had erected residential and cultural barriers tended to display its philanthropy in ways which differed from those of the emergent elite of the "walking city" of the mid nineteenth century. By the late nineteenth century the kind of charity most likely to succeed would operate on a large scale over the whole city, and need a massive architectural edifice which would reflect glory on the town. The Infirmary was most important of these institutions, imposing enough to feature on postcards sold in Cardiff in the Edwardian period, but the same applied to a lesser extent to the Blind Institute and the Seamen's Hospital. Recognising this,

45 Parish of Canton St. John, Report and Statement of Accounts, 1906, p. 7.

46 Evans, "'The First Charity in Wales"', pp. 319, 341-45; P. Stead, Coleg Harlech: The First Fifty Years (Cardiff, 1977), pp. 3-4; M. Sanderson, The Universities and British Industry, 1850-1970 (London, 1972), ch. 5; Cardiff Chamber of Commerce, Annual Report, 1914, p. 26. 
the latter's organisers appealed to civic pride in making their attempt to replace the ageing warship the Hamadryad with a permanent shore building. The public were urged to provide "a stately structure, permanent and substantial, worthy of the designation of the CARDIFF SAILORS' HOSPITAL". ${ }^{47}$ When this failed to produce a response, the coupling of civic pride with the Diamond Jubilee ultimately did: "It was only natural that Cardiff, one of the leading ports of the Kingdom, should be well to the front in the charitable enterprises of the Diamond Jubilee Year." ${ }^{, 48}$ The building which resulted from this appeal was later cited as an example of the general "worthiness" of the town, and as part of its claim to have the National Library and National Museum of Wales located there. In the Edwardian period Cardiff Infirmary's great expansion was founded upon appeals to civic pride. The Cardiff Sailors' Rest tried to use similar tactics in a particularly open manner.

"Cardiff is the chief port of the world", so say the Board of Trade Returns, and it is desirable that it should have the best "Sailors Rest" in the World. If you are of this opinion kindly express it by sending a donation. ${ }^{49}$

Gareth Stedman Jones has argued that in the nineteenth century many charities faced the problem of "deformation of the gift". The gift essentially a personal relationship - lost many of its defining features in an urban context, and there were fears about the loss of obligation. Yet, as Stedman Jones notes, social control could be in conflict with the desire for prestige, and it should be added that a gift could confer status and prestige even if it were "deformed".$^{50}$ Large institutions like the Infirmary gave Cardiff's middle class a collective status, they were a reflection of the achievement of a class and of a city. If charities had a declining utility for control and obligation, certain kinds of charity had life left in them in the dimension of prestige. The range of such charities was quite small and they needed to indulge in vigorous fund-raising activities in order to survive. They were only a partial exception to the generalisation that Cardiff lacked, not only the resources but, more importantly, the kind of elite which would make philanthropy vigorous and active. Charitable innovation had to look elsewhere for its support - especially to the professions.

47 CT, 7 March 1874; postcard sent from Cardiff, 21 August 1911, showing Cardiff Infirmary, in my possession.

48 Cardiff Seamen's Hospital, Programme, Guide and Souvenir of the Grand Bazaar (Cardiff, 1899).

49 Evans, “"The First Charity in Wales", p. 341 ; Cardiff Sailors' Rest, Official Handbook of the Sale of Work, 1899.

50 Stedman Jones, Outcast London, op. cit., ch. 13. 
Certain new directions in philanthropy became evident in the late nineteenth century. The Cardiff Charity Organisation Society started its operations in 1886, and from the beginning it felt embattled. The Cardiff Times was not enthusiastic about the prospect of such a society, hoped that it would not emulate the London society in spending more on investigation than relief or pry too deeply into the lives of applicants. Overall it felt it would have been better if another name had been found without the overtones of charity organisation. ${ }^{51}$ Charity organisation was in essence a response to the geographical separation of classes and the impact which this had on charitable relief. In the 1880 's there were many complaints in the Cardiff press that the middle-class districts were full of beggars who worked systematically through them, offering abuse and leaving chalk marks to guide their colleagues to favourable pickings. Also there had been complaints that soup kitchens were exploited - the applicants asked for more and brought with them jugs smelling of beer. One organiser felt that the only solution was to sell soup at a subsidised price so as to attract only the "respectable" poor. ${ }^{52}$

The Cardiff Charity Organisation Society built on these fears and also upon various criticisms of existing charities. Established charities were localised, overlapping and often run by religious bodies, it argued, and this made it possible for applicants for charity to move from one to another in search of aid and exploit this situation of philanthropic anarchy. Against the common complaints made by Cardiff charities that they were badly supported it offered the argument that there would be plenty of aid for the "deserving" if only rigorous efforts were made to exclude imposters, by means of strict investigations of circumstances, and by compiling a register of those relieved. Professor G. Chatterton Richards argued that indiscriminate almsgiving was not charity, as "Charity implies personal contact and sympathy between the giver and the recipient", but "nowadays an individual by himself cannot always be an almoner of relief. He must work in concert with others." The Charity Organisation Society was to provide the medium for this co-operation.

The Charity Organisation Society desires to be a centre, a connecting link between diverse agencies, a common meeting ground where every creed and class may co-operate for the common object, and in homely language, a

51 CT, 30 January 1886. For its origins see Western Mail, 26 January; SWDN, 25 January, 23 February, 3 and 8 March 1886.

52 CT, 18 March 1871; 3 January and 14 February 1880; Western Mail, 18 November 1886; Cardiff COS, Annual Reports, 1886-1914, passim. 
means of preventing "too many cooks spoiling the broth", otherwise how is "overlapping" that fruitful source of mischief, to be avoided in a large town, if chapel is isolated from chapel, society from society, and there is no common meeting ground. ${ }^{53}$

In seeking to organise, the Society spent relatively little of its small income on relief; instead it paid a full-time agent to investigate the circumstances of applicants so that the committee could reach its decision in an informed manner. In addition it offered protection from the impositions of beggars, and to drive "undesirables" out of the middle-class neighbourhoods. Little of this was new; anti-mendicity societies had a provenance in other towns going back to the early part of the nineteenth century at least - especially in towns like Bath, where the rich habitually congregated in large numbers. The distinction between the "deserving" and the "undeserving" poor was at least as old as the Elizabethan Poor Law and was a central element in the Protestant ethic. ${ }^{54}$ What distinguished the Charity Organisation Society was its commitment to a rigorous investigation of need, which was then to be coupled with the appropriate remedy. The remedies varied, but wherever possible doles were to be avoided. Instead the Cardiff Charity Organisation Society tried to make its applicanıs self-supporting; some were sent to convalescent homes, others given hawkers' licences and a stock of goods, still others rail tickets, clothes or tools to enable them to work. It had a coffee stall, which was rented to a suitable applicant. Some were directed to other sources of relief and other relieved out of the society's own limited funds.

The Charity Organisation Society Committee had a significant sprinkling of academics and their wives, a feature not found in the committee of the Infirmary. ${ }^{55}$ Professors were prominent in its councils and for them the Charity Organisation Society offered a means of philanthropy to vie with those of the richer; the lesser amount that their pockets afforded could go further when applied scientifically and eked out with personal service. Perhaps, the professional and academic classes were more inclined to

53 G. Ch. Richards, M.A., The Evils of Indiscriminate Charity (Cardiff, 1894), pp. 4-7 (bound with COS Annual Reports, Cardiff Public Library); SWDN, 5 December 1893. 54 Cardiff COS, Annual Reports, passim; Owen, English Philanthropy, op. cit., pp. 110-12; Ch. Hill, Change and Continuity in Seventeenth-Century England (London, 1979), p. 95.

55 This statement is based on membership and occupational data in Cardiff COS, Annual Report, 1895; Infirmary, Annual Report, 1895; Daniel Owen and Co's Wright's Directory, 1894-95. 
believe in vigorous self-help doctrines than were the entrepreneurs. Businessmen might recognise that luck had been important to them in their careers, but for professionals diligent work through a series of hurdles could make self-help seem to be a fundamental principle of social life. ${ }^{56}$ The Charity Organisation Society criticised established philanthropy and in turn found it difficult to obtain the co-operation of many of the charitable agencies, though some sporadic co-operation was achieved. Its failure lay in its concentration upon just one element in the gift relationship, the personal bond as expressed in the dimension of control or obligation. It could offer less in prestige; the rigours of detailed investigation left an unpleasant taste, which it was difficult to blend with the flavour of openhanded benevolence which gave prestige to philanthropists. Its small-scale work produced no edifices which proclaimed the civic virtues of the rich and their city. It challenged the separation of charities upon doctrinal lines when churches must have seen their relief-giving agencies as an important element in maintaining their members in difficult times and as a means of securing some more adherents. Above all it was too rational and represented the invasion of the felicific calculus into a field which had often been characterised more by sentiment, religion and fear than by rigorous thought.

Walter Houghton explains the benevolent spirit of the Victorian period as a reaction of the heart to a society which the intellect could not comprehend. The Charity Organisation Society in trying to impose distinctions clearly fell victim to an exceedingly narrow view of the functions of philanthropy. If orthodox charity offered some reassurance to members of the middle classes entertaining doubt about their salvation or their prestige, it was not necessary for this gift to convey obligation for philanthropy to have some important functions. Kellow Chesney argues that though charitable frauds were well known, the middle classes still gave money to beggars in the tacit recognition of the inequalities of society. "It was not just ignorance that supported the army of professional beggars, it was understanding." This was much closer to reality than the cold rationalism of the Charity Organisation Society. The wealthy gave some of their money to the Charity Organisation Society and sat on its committees, but adjusting ends and means by the rigorous exercise of logic had little appeal. Beatrice Webb cites a case in London which well illustrates this point. An old gentleman sitting at the end of the table gave sixpence to an unsuccessful applicant and was reprimanded by Canon Barnett for his

${ }^{56}$ H. Perkin, The Origins of Modern English Society, 1780-1880 (London, 1969), ch. VII, has a good discussion of class ideals. 
delinquency. There were many in Cardiff who also found the new ideas strange. ${ }^{57}$

The Cardiff Charity Organisation Society rested upon a professional base and presented a challenge to existing philanthropy by the rigorous application of its own ideas. It was an adaptation to the physical separation of classes which characterised the late nineteenth century - essentially an attempt to "moralise" by "scientific" rather than religious means. The university settlement shared some of this background - the concern for physical separation and the professional basis -, but it rejected the felicific calculus as the foundation of social relations. It was the response of a younger generation of professionals to the situation of the latenineteenth-century city, and as such its emphases were very different from those of the COS. This should not blind us to the fact that it was another response to the changed urban structure of Cardiff and that as such it shared a common context with the COS.

The immediate origins of the Cardiff university settlement remain rather obscure, but certainly in the mid 1890's a group of students at the University College of Wales, Aberystwyth, showed an interest in establishing a settlement in Wales and decided that Cardiff was the most likely location. Amongst these students was Tom Jones, later to be deputy secretary to the Cabinet. In 1896 he wrote to ILP member Sam Hobson, who had, until recently, been living in Cardiff. Hobson's reply provides an interesting insight into philanthropy in Cardiff.

Cardiff is undoubtedly sadly in need of an active university settlement. It is intellectually dead. I know of no town in the kingdom so utterly destitute of real vitality and idealism as Cardiff. It is equally destitute of scientifically applied social effort. It is heart rending to see its social problem absolutely ignored by the conformist and non-conformist philistines who flounder helplessly in those methods of charity dear to the heart of Samuel Smiles and the Charity Organisation Society.

He advised that the work would need to be unsectarian, "Religious in our sense of the word, secular in the ordinary sense of the word". The East Moors and Splott would be the best areas in which to work, as this would avoid working amongst the Irish, which would stir up theological controversy.

Hobson thought that support would come chiefly from the College and some of the clergy in Splott, and that the Church of England would give more support than the nonconformists. Some local socialists might help,

57 W. E. Houghton, The Victorian Frame of Mind (New Haven, 1957), pp. 273-81, 291-97; K. Chesney, The Victorian Underworld (London, 1970), pp. 222-28; B. Webb, My Apprenticeship, with an introd. by N. MacKenzie (Cambridge, 1979), p. 197. 
and it was felt that if some of the influential men could be interested the enterprise would never lack money. He suggested John Cory, Alfred Thomas, Lord Windsor, W. T. Lewis and others as possible supporters. Tom Jones also wrote to Benjamin Evans of the Cardiff ILP and to Professor MacKenzie of the University College and the Charity Organisation Society. Evans also thought that the younger clergy of the Church of England were a good bet for providing support, as many of them belonged to the Christian Social Union. MacKenzie warned of religious difficulties and was more pessimistic about the prospect of support. All stressed the need to tread carefully. ${ }^{58}$ Cardiff, it was emphasised, was a place where money would be easier to get than personal help, it liked the big idea rather than the small-scale and unspectacular, and this was a problem for both the Charity Organisation Society and the settlement.

The settlement opened in 1901. An article in the University College of South Wales and Monmouthshire Magazine proclaimed its principles, and they provide an interesting commentary on the development of ideals of personal service in the early twentieth century. The "civilising mission" to the poor was rejected, there was to be no attempt by the "West" to destroy the gods of the "East", classes were to be brought together rather than merged. The term settlement itself was questioned, it seemed to suggest that pioneers of civilisation would pitch their tents amongst the barbarians. It recognised social divisions and thought friendship could bridge the gap.

A settlement is primarily an institution for bringing together the various classes in the community which live apart. [This involves] individuals cooperating for the common good with all the energy with which each acts for himself. This makes municipal enterprise a possibility, slums and vulgar display an absurdity, and the problem of poor relief easy.

Social division had made a mockery of the ideal of citizenship.

"Citizen" does not mean so much to us as it did to the Ancient Greeks, for the fascinating complexities of our social life have obscured its unity: and it cannot until we have made more real the common life of citizenship. A settlement, in brief, is a social centre and a social force for achieving this. ${ }^{59}$

Despite such protestations the influencing of the working class was clearly a part of its aims and practice. Concerts and a billiard table were seen as counter-attractions to the pub: "We aim at making the club a centre of enlightened influence in the district", proclaimed one annual report in

58 S. Hobson to Tom Jones and others, 25 February 1896; J. S. MacKenzie to Tom Jones, 28 February; B. Evans to Tom Jones, 1 March, Thomas Jones Papers, Class X, Vol. 2. 59 University College of South Wales and Monmouthshire Magazine, XIII (1900). There is a copy in the Thomas Jones Papers, ibid. 
referring to its men's club. Influence was more subtle than in the earlier explicitly Christian ventures in this field. Most of the members of the men's club were artisans or better-off workers, and the lads' club showed a similar preponderance, though it admitted some "rougher" boys in order to prevent its becoming too "aristocratic" and "collared". Co-operation between classes clearly had its limits.

The settlement had four clubs for men, women, lads and girls, and (unusually for British settlements) had no religious affiliation. It provided rational recreation of a non-religious character and was heavily supported by the Thompson family, who were known in the city for their support of Sunday opening of rational amusements, a stance which led them to conflict with the sabbatarianism of the dominant nonconformist groups. The clubs provided sports, a gymnasium, concerts, singing and many other recreations. The clubs were allowed a degree of self-government in an attempt to work with people rather than for them, and the debates had a strongly political and "progressive" tone. Its mock parliament had a Labour majority almost forty years before Westminster did. Female suffrage was favourably discussed. The Poor Law Reports of 1909 were discussed with the Webbs present, and other debates or lectures touched on unemployment, the budget, railway amalgamation, the House of Lords and labour exchanges. Clearly, though the settlement did aim at changing behaviour, it could only have an impact if it was prepared to be less doctrinaire and narrow than moralisers of the poor in the 1860's had been. ${ }^{60}$ It does genuinely seem to have acknowledged diversity of viewpoint and to have respected working-class views. Moralisers of the poor had not recognised the existence of working-class values and culture; "civilisation" was to be imposed. Settlement workers may not have seen the people of the East Moors as equals, but they were obliged to give some weight to the views of their clients and to see the need for providing joy in otherwise dull lives. If the moralising efforts of the 1860's derived their impetus from Evangelical religion, those seeking to enrich working-class lives in the first decade of the twentieth century gained some of their inspiration from "the religion of socialism". The settlement had its ups,

60 Welsh University Association for the Furtherance of Social Work, Cardiff Branch Annual Reports, 1901-14; CT, 24 June and 15 July 1899; 19 October 1901; 18 October 1902; 11 July 1903. B. M. Bull, The Cardiff University Settlement (Cardiff, 1965), gives a good account. G. Glasgow, Ronald Burrows, A Memoir (London, 1924), pp. 80-118; Daunton, "Aspects", pp. 490-91; K. Inglis, Churches and the Working Classes in Victorian England (London, 1963), pp. 159-60. Settlements in the United States (like Cardiff) tended to be secular, see A. F. Davis, Spearheads for Reform (New York, 1967), pp. 15-16. 
downs and dissentions, but was killed by the First World War when it was requisitioned as a hospital, after which it never again resumed its old activities and was wound up in 1922. The First World War saw the death or modification of many other philanthropic activities, and is a fitting point at which to conclude a survey of nineteenth-century charities.

\section{VII}

How did philanthropy adapt to the late-nineteenth-century city? It is evident that the social structure and development of the particular town is a vital consideration; in Cardiff rapid growth from small beginnings and an elite whose economic interests stretched into the hinterland with a consequent lack of close involvement in the town itself imposed severe limits on philanthropy as a form of social policy. This was well attested in the press and in the complaints of the philanthropists themselves. ${ }^{61}$ In a sense it was an extreme case, but perhaps not wholly untypical. Only further research on other areas can determine this - and there is no need to accept Professor McCord's case-study of Newcastle as any more typical. Such studies would need to relate the range of philanthropic resources to the extent and the particular local problems of urban growth. Also they would need to emphasise the congruence between philanthropy and needs of the wealthy and the consequent limits on benevolence that the local social structure could impose.

A further issue needs brief discussion. Did charities induce much "cooperation and sympathy" between classes? The response of the poor to nineteenth-century charity is probably the subject on which the sources are most silent, but some tentative arguments can be made. Certainly there is some evidence of gratitude for charity - letters to the press offering thanks, for instance. ${ }^{62}$ But this is not one's general impression of the evidence, and we should be sceptical of gratitude - Afro-American slaves knew full well how to play "Sambo". ${ }^{63}$ William Johnstone, the author of some sycophantic pen portraits of the Cardiff middle class was a patient at the Infirmary around the turn of the century and was at some pains to defend the institution's good name. There seems to have been a strong current of complaints, mainly about food, which Johnstone tried to minimise by the ad hominem argument that the complainers were either "dark complexioned" or "from the hills". His own defence is evidence for some

${ }^{61}$ E.g., CT, 9 October 1863; 15 April and 24 June 1871; 19 July 1884; SWDN, 23 November 1893.

62 SWDN, 29 November 1893.

${ }^{63}$ See E. Genovese, Roll, Jordan Roll; The World the Slaves Made (New York, 1974); K. M. Stampp, The Peculiar Institution (New York, 1956). 
degree of dissatisfaction and discontent: "There are others also, who, while they ought to feel grateful are loud in their disparagement." 64 In 187720 patients were discharged for reasons which included breaches of discipline, in 188833 , and in 1909177 ; these were small proportions of the number of patients and, bearing in mind the rising number of patients and difficulties in classification, they do not represent any clear rise. They do represent some conflict and dissatisfaction, however. ${ }^{65}$

The frequent exploitation of charitable overlapping and frauds were not all fantasies of the Charity Organisation Society and had some basis in fact, suggesting a rather cynical attitude towards charities on the part of the poor. Imaginative writers who were also close observers of working-class society provide examples. In Arthur Morrison's Jago (admittedly violent and not typical of working-class life) a minister gained respect.

Once he had made it plain that he was no common milch cow in the matter of gratuities: to be bamboozled for shillings, cajoled for coals, and bullied for blankets; then there became apparent in him qualities of charity and loving kindness, well-judged and governed, that awoke in places a regard that was in a way akin to affection.

Jagos used to taking shillings from the gullible by feigning religious conversion, respected a man who could not be exploited, not one who gave freely. His charity based on a club, sewing meetings and singing had more impact than did doles. ${ }^{66}$ Walter Greenwood also provides evidence that relief could be seen quite instrumentally; one of his characters remembers the situation at the turn of the century: "Me ma an' her man was blue (Conservative) or they were red (Liberal) just depended on which o' t' two gev most coal an' blankets." 67 Nineteenth-century charities encouraged such a response because they were used to further sectarian loyalties. Doles were related to specific churches or to a particular group like the Scots, served by the Caledonian Society. Support for a Dissenting Adult Mission (for the Deaf and Dumb) was encouraged in the following way: "Will the dissenters of this town and neighbourhood be content to know that the Episcopalian institution is in a flourishing state, whilst the mission under our protection is languishing into decay?" A Church of England vicar was accused of using Christmas dinners for the poor in a sectarian manner. In 1881 the Cardiff Liberal Association complained that the second Marquess of Bute had given a treat to all the children of Cardiff, where the Liberal

64 W. Johnstone, The Welsh at Home (Cardiff, 1904), ch. XXXVI, esp. p. 371.

65 Cardiff Infirmary, Annual Reports, 1877, 1888 and 1909.

66 A. Morrison, A Child of the Jago (London, 1971), pp. 104-05.

67 W. Greenwood, Love on the Dole (London, 1933), p. 217; see also p. 144. 
majority was small, but only to Church of England children in Aberdare, where the Liberal majority was unshakable. ${ }^{68}$

The feeling that charity undermined independence and the clear intention of many philanthropists of obtaining an obligation from their charity, far from inducing "co-operation and sympathy", made charity something to be avoided by those that could, and something to be exploited by those that could not. The attempt to impose obligation itself tended to weaken the efficacy of charity as a means of social control; "It was the [.. . ] sense of what the charitable act feels like to the recipient, from prolonged experience of the habits and manners of most charitable institutions", which induced the usage "as cold as charity" in the eighteenth century. Raymond Williams points out that the word became so compromised that apart from the legal definition of benevolent institutions the word is rarely used, and that government departments advertise benefits "not a charity, but a right". ${ }^{99}$ Nineteenth-century benevolence was moulded by the configuration of society, and attempts to soften its harsh outlines with "cooperation and sympathy" could only succeed in throwing those outlines into stark relief.

${ }^{68}$ Cardiff COS, Directory of Charities, 1910: CT, 3 October 1875; 20 August 1881; 5 December 1885 .

69 R. Williams, Keywords (London, 1976), p. 46 (sub Charity). 